Reprinted with permission from: Weed Science, 1992. Volume 40:275-280.

Published and copyrighted by: Weed Science Society of America. http://www.wssa.net

\title{
Economic impact of leafy spurge (Euphorbia esula) in North Dakota ${ }^{1}$
}

\author{
F. LARRY LEISTRITZ, FLINT THOMPSON and JAY A. LEITCH
}

Leistritz and Leitch are Prof. and Assoc. Prof., respectively, Dep. Agric. Econom., North Dakota State Univ., Fargo, 58105. Thompson is Agric. Ext. Agent, Eau Claire, W1 54703.

\begin{abstract}
:
Leafy spurge is a serious problem because of the speed with which it spreads and the difficulty of controlling it with available means. A rangeland economics model was developed to estimate the economic impacts of leafy spurge infestation on both ranchers and regional economies. A leafy spurge-induced carrying capacity reduction of about 580,000 animal unit months (AUMs), or enough for 77,000 cows, reduced ranchers' annual net income nearly $\$ 9$ million. Ranchers did not spend another $\$ 14$ million on input costs, which reduced regional business activity. The regional impacts are about $\$ 75$ million in reduced business activity for all sectors. These impacts on rancher incomes and regional economies suggest the potential economic returns of leafy spurge control could be substantial. Nomenclature: Leafy spurge (Euphorbia esula L. \#² EPHES).
\end{abstract}

\section{Additional index words:}

Regional impacts, rangeland, income, EPHES.

\section{Introduction}

Undesirable plants are a problem for managers of publicly or privately owned grasslands because they reduce usefulness of the land for livestock grazing. Some plants also may be detrimental to other grassland functions (e.g., wildlife habitat, watershed). Because reduction of the land's ability to support livestock grazing almost always leads to

\footnotetext{
${ }^{1}$ Received for publication April 8, 1991, and in revised form September 13, 1991.

${ }^{2}$ Letters following this symbol are a WSSA-approved computer code from Composite List of Woods, Revised 1989. Available from WSSA, 309 West Clark Street, Champaign, IL 61820.
} 
reduced income to stockgrowers, mechanisms to control spread of such plants or even to eliminate them entirely have attracted considerable interest $(2,4,5)$. However, because costs of control using herbicides are often substantial compared to improved grazing capacity, especially in extensive rangeland environments, such treatments often appear to be too costly for private landowners $(12,13)$.

Concerns about the cost effectiveness of chemical treatments and growing public concerns about environmental safety have led to more research on control of some weed species using insects or microorganisms that adversely affect the plant (1). To evaluate the economic feasibility of either available chemical controls or of future chemical and biocontrol technologies, however, requires a better understanding of the economic effects of weed infestations. Such information also may be useful for allocating resources to develop and refine new control technologies.

Economic effects of undesirable range plants include direct effects, such as those experienced by landowners and ranchers, plus secondary effects on other sectors of the rural economy. A change in an area's resource base or agricultural production practices can affect both agribusiness firms and local trade and service sectors $(10,16)$. Decisions regarding public sector support for research to develop better control methods and/or public sector cost sharing for treatment efforts should take into account such secondary (multiplier) effects.

Leafy spurge, a perennial, is a widely established weed in the northwestern United States and western Canada. Within North Dakota, over 485,600 ha or about $9.2 \%$ of the state's 5.3 million untilled ha were estimated to be infested in 1987 (14). Leafy spurge, a native to Europe and Asia, was introduced to North America in 1827 and first was reported in North Dakota in 1909 (15). Leafy spurge presents special problems to rangeland and pasture owners because it can reduce livestock carrying capacity by as much as $75 \%$ (17).

Leafy spurge is a particularly serious problem because of the speed with which it spreads and the difficulty of control with available herbicides. North Dakota had an estimated 80,900 ha with leafy spurge in 1962; the area had more than doubled to 171,400 ha by 1973 , and had doubled again to 348,800 ha by 1982 (15). The speed with which leafy spurge has been spreading is particularly alarming when the magnitude of control efforts is considered. During 1985 to 1987, the total expenditures for leafy spurge control exceeded $\$ 1$ million per year (20).

The purpose of this study was to develop a method to estimate the direct and secondary economic effects of reduced livestock carrying capacity from leafy spurge infestation and to conduct a case study in North Dakota. The specific objectives were to estimate the economic effects of leafy spurge infestation on landowners for both reduced income derived from grazing and reduced land values and to estimate the impacts of leafy spurge infestation on the regional economy. 


\section{Materials and methods}

A livestock carrying capacity function was developed through a literature review and consultation with agronomists and range scientists involved in leafy spurge research (19). Estimating the effect of reduced carrying capacity on landowners' income required establishing a value for units of lost carrying capacity. Two approaches were used to estimate the value of lost carrying capacity measured in animal unit months (AUMs) ${ }^{3}$ an analysis of historical rental rates for pasture and a ranch budget analysis. An AUM is the amount of feed (about $12 \mathrm{~kg}$ of dry matter per day) one mature cow weighing about $454 \mathrm{~kg}$ or her equivalent requires per month in forage consumption (18).

The impact of leafy spurge infestation on the regional economy was estimated, using the North Dakota Input-Output Model(3). Input-output analysis is a technique for quantifying interdependencies or linkages among sectors (groups of similar economic units) within an economic system. Input-output analysis frequently is used to estimate effects of an initial change in a particular sector on other sectors of the economy (local, state, and national). The input-output model used in this analysis has 17 sectors and is based on primary survey data. The model is closed with respect to households, and total gross business volume of the trade sectors is used (both for expenditures and receipts in the transactions table) rather than value added by these sectors.

Carrying capacity is defined as the highest sustainable stocking rate that can be achieved. Leafy spurge infestation reduces livestock carrying capacity by reducing forage production due to competition and because cattle totally or partially avoid leafy spurgeinfested sites, especially early in the grazing season (11).

A relationship between increased leafy spurge infestation and reduced carrying capacity was developed through review of recent literature (21). The carrying capacity function was estimated in consultation with a group of range science and weed science specialists and appears to be consistent with recent experimental results $(6,11)$.

Impacts of leafy spurge on stock growers were estimated by first estimating carrying capacity of the state's grasslands in the absence of leafy spurge and the carrying capacity reductions from leafy spurge infestations. Effect of the loss of grazing on incomes of stockgrowers and landowners and effect on land values were estimated.

Carrying capacity of North Dakota grasslands without leafy spurge was estimated from USDA Soil Conservation Service information (22). Carrying capacity estimates were developed for five distinct regions in North Dakota (Figure 1). Each region included counties that had similarities in soil and climatic conditions, which generally imply similarities in carrying capacity.

\footnotetext{
${ }^{3}$ Abbreviations: AUM animal unit month.
} 


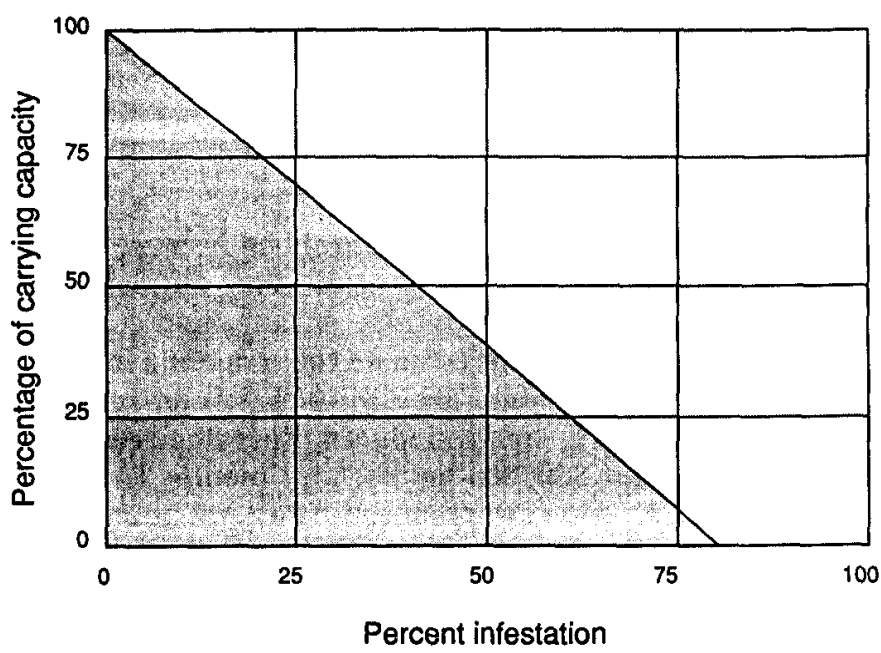

Figure 1. Regions for leafy spurge impact analysis in North Dakota.

Effect of leafy spurge infestation on carrying capacity was estimated for the five regions by dividing the reported ha of leafy spurge by the total area of pasture and rangeland and applying the carrying capacity model. Data on the area affected by leafy spurge were obtained from annual surveys conducted by the North Dakota Department of Agriculture (16). Data on the area of pasture and rangeland came from the U.S. Census of Agriculture (21). The resulting estimates of leafy spurge infestations are shown in Table 1.

Table 1. Pasture and rangeland and area infested by leafy spurge, North Dakota, 1988.

\begin{tabular}{lccc}
\hline Region & Total pasture and rangeland $^{\mathrm{a}}$ & Leafy spurge present $^{\mathrm{b}}$ & Infestation $^{\mathrm{a}}$ \\
1 & $h a$ & $h a$ & $\%$ \\
2 & $2,347,115$ & 90,794 & 3.9 \\
3 & 911,434 & 36,977 & 4.1 \\
4 & 364,224 & 112,814 & 31.0 \\
5 & 325,800 & 67,858 & 20.8 \\
Total & 123,658 & 36,132 & 29.2 \\
\hline
\end{tabular}

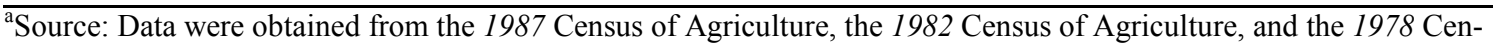
sus of Agriculture (21).

bource: North Dakota Department of Agriculture, unpublished data, 1988.

\section{Results and discussion}

The relationship between percent of a pasture's area covered by leafy spurge and reduced carrying capacity appears to be best approximated by the following linear function:

$$
\text { C.C. }=100-1.25 \text { (P.I.) }
$$


where

$$
\begin{aligned}
\text { C.C. }= & \text { carrying capacity } \\
\text { P.I. }= & \text { percent infestation of rangleland or pasture } \\
& \text { covered by leafy spurge }
\end{aligned}
$$

A leafy spurge infestation covering $80 \%$ of the area in a pasture would reduce carrying capacity to zero from a practical range management standpoint (Figure 2) primarily because cattle partially or totally avoid leafy spurge-infested sites (11). Hein (6) supported this conclusion and reported that a leafy spurge canopy cover of less than $10 \%$ is necessary to achieve $50 \%$ cattle forage utilization.

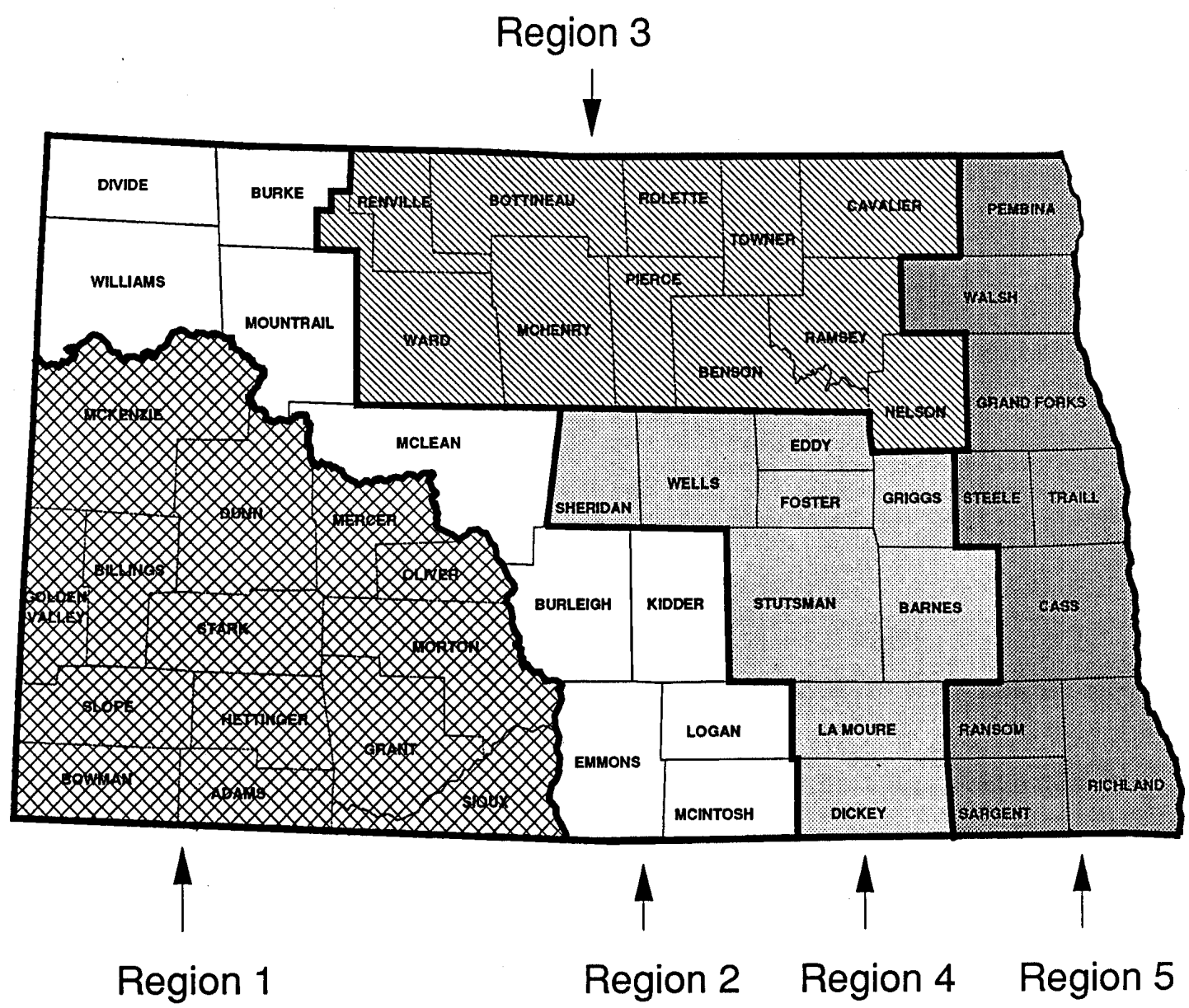

Figure 2. Estimates of reduced carrying capacity caused by various leafy spurge infestation rates (20). 
When the carrying capacity model was applied to the percent infestation values from Table 1 and the resulting percentage reduction in carrying capacity was applied to baseline carrying capacity, an estimate of the reduction in carrying capacity was obtained (Table 2). Statewide, the leafy spurge infestation was estimated to reduce carrying capacity about 577,000 AUMs, which is equivalent to the forage needed for a herd of about 77,000 cows.

To establish a value for the reduced AUMs, grazing land rental rates were compared to an estimated change in a rancher's income associated with the loss of a portion of carrying capacity and, hence, reduction of the livestock herd. This latter estimate was obtained from a ranch budget model (7).

Table 2. Baseline carrying capacity, percent infestation, and effect of leafy spurge on carrying capacity by region.

\begin{tabular}{lccc}
\hline Region & Baseline carrying capacity & Infestation & Effect of leafy spurge \\
\hline & $A U M$ & $\%$ & $A U M$ \\
1 & $2,471,151$ & 3.9 & $-123,600$ \\
2 & $1,126,061$ & 4.1 & $-56,300$ \\
3 & 507,046 & 31.0 & $-196,500$ \\
4 & 496,837 & 20.8 & $-130,400$ \\
5 & 193,537 & 29.2 & $-70,200$ \\
Total & $4,794,632$ & 8.7 & $-577,000$ \\
\hline
\end{tabular}

Grazing land rental rates are a useful measure of the value of grazing because they are published annually for six farming regions in the state and, under conditions of a competitive market, should approximate closely the contribution of a unit of grazing to a rancher's income (8). Rental rate variations among tracts or areas should reflect differences in productivity and differentials in supply and demand conditions (9). Variations over time should reflect differences in profitability of livestock production and possible changes in availability of grazing land.

Average per-hectare rental rates for range and pastureland for six North Dakota farming areas for 1984 to 1988 were obtained from Johnson (8). These rates were divided by the AUMs per ha or multiplied by the ha per AUM to obtain a rental rate per AUM. Rental rates per AUM computed for each of the six farming areas were assumed to be applicable to all counties in a given area. These county rental rates were then weighted by the areas of pasture and rangeland in each county to estimate the value of grazing for each of the five state regions (Table 3). The average rental rate per AUM ranges from \$14.71 for Region 5 to $\$ 15.54$ for Region 1 .

An enterprise budget was used as an alternative method to estimate the value of grazing. Because leafy spurge reduces carrying capacity, ranchers' herd sizes are also reduced. Reduction in ranch income from the decrease in herd size divided by the decrease in AUMs that caused it was the estimate of the value of grazing AUMs. The enterprise budget, developed by Hughes et al. (7), reflects levels of livestock prices, input costs, and 
production technology for North Dakota during the late 1980s. A ranch was assumed to have a 100 -cow herd. When a $25 \%$ leafy spurge infestation was assumed, carrying capacity was reduced $31 \%$, and the 100 -cow herd was cut to 69 head (Figure 2). Herd reduction decreased ranch net income (or return to operator labor, management, and equity) $\$ 3,634$. When the reduction in ranch income was divided by the reduction in AUMs (232), a value of $\$ 15.66$ per AUM was obtained.

Table 3. Rental rate per $\mathrm{AUM}^{\mathrm{a}}$, reduced AUMs, and value of reduced AUMs.

\begin{tabular}{lccc}
\hline Region & Rental rate & Reduction & Value of reduced AUMs $^{\mathrm{b}}$ \\
\hline & $\$ A U M$ & $A U M s$ & $\$(000)$ \\
1 & 15.54 & 123,000 & 1,900 \\
2 & 13.85 & 56,300 & 800 \\
3 & 15.45 & 196,500 & 3,000 \\
4 & 14.83 & 130,400 & 1,900 \\
5 & 14.71 & 70,200 & 1,000 \\
State total & 15.03 & 577,000 & 8,600 \\
\hline
\end{tabular}

${ }^{\mathrm{a} A U M}=$ animal unit month

${ }^{\mathrm{b}}$ Rental rate times reduction in AUM

Comparing results of the cash rent and enterprise budgeting approaches indicates that they result in similar values for grazing AUMs, i.e., a value of $\$ 15.66$ per AUM for the budgeting approach vs. a range of $\$ 14.71$ to $\$ 15.54$ per AUM for the rental rate method. Because values obtained from the two methods were similar and because the rental rate approach was considered to reflect regional variations better, the rental method was used as the basis for subsequent analysis.

When values per AUM calculated by the rental rate method were applied to estimates of reduced AUMs from present levels of leafy spurge infestation, a total annual value of $\$ 8.6$ million was obtained (Table 3). Income loss to stock growers and landowners averages about $\$ 15$ per AUM or $\$ 24.70$ per infested ha statewide. If this annual income loss was discounted at $10 \%$, the resulting value of $\$ 247$ per ha would represent an estimate of what a landowner could afford to pay per ha (on a one-time basis) for permanent eradication of leafy spurge.

From 1984 to 1988, grazing land rental rates have averaged \$20.65 per ha, and the sale prices of such lands have averaged $\$ 329$ per ha. If this value-to-rent ratio of 15.9 were applied to the estimated \$8.6 million loss of value of grazing AUMs, the estimated reduction in grazing land value would be $\$ 137$ million.

\section{Impacts on the state's economy}

The secondary impacts of leafy spurge infestations on the state's economy arise from two sources: reduced income to ranch operators and landowners from the loss in grazing value and decreased production expenditures associated with ranchers' herd reductions. Decreases in production expenditures were estimated using the ranch budget (7). State- 
wide, reduced production expenses associated with decreased carrying capacity from leafy spurge infestations were estimated to total about $\$ 14.4$ million. These reduced expenditures, which also are decreases in revenues for input suppliers, together with the estimated $\$ 8.6$ million in reduced net income to landowners and ranchers constitute the direct impact of present levels of leafy spurge infestation (Table 4).

Table 4. North Dakota business activity decreases associated with present leafy spurge infestation.

\begin{tabular}{|c|c|c|c|c|}
\hline \multirow[b]{2}{*}{ Sector } & \multirow{2}{*}{$\begin{array}{c}\text { Baseline } \\
\text { business activity } \\
\text { (assuming no } \\
\text { leafy spurge) }\end{array}$} & \multicolumn{3}{|c|}{ Impact of present leafy spurge infestation } \\
\hline & & Direct & Secondary & Total \\
\hline & & - & 9) & 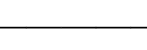 \\
\hline Agriculture, livestock & 1,472 & 699 & 1,793 & $32,244^{*}$ \\
\hline Agric. crops & 3,673 & 9,197 & 1,482 & 10,679 \\
\hline Nonmetal mining & 50,000 & 0 & 134 & 134 \\
\hline Construction & 732 & 0 & 1,760 & 1,760 \\
\hline Transportation & 92 & 620 & 244 & 864 \\
\hline Comm. \& public utilities & 662 & 672 & 2,053 & 2,725 \\
\hline $\begin{array}{l}\text { Agric. processing \& } \\
\text { miscellaneous manufacturing }\end{array}$ & 2,146 & 0 & 2,432 & 2,432 \\
\hline Retail trade & 5,341 & 3,265 & 16,035 & 19,300 \\
\hline Finance, insurance, real estate & 1,114 & 41 & 3,465 & 3,506 \\
\hline Business \& personal service & 490 & 0 & 1,316 & 1,316 \\
\hline Professional \& social service & 523 & 0 & 1,660 & 1,660 \\
\hline Households & 7,981 & 8,749 & 16,819 & 25,568 \\
\hline Government & 681 & 0 & 2,255 & 2,255 \\
\hline Coal mining & 135 & 0 & 0 & 0 \\
\hline Electric generation & 226 & 0 & 0 & 0 \\
\hline Petroleum exploration/extraction & 884 & 0 & 0 & 0 \\
\hline Petroleum refining & 121 & 0 & 0 & 0 \\
\hline TOTAL & 26,321 & 23,243 & 51,448 & $104,443^{\mathrm{a}}$ \\
\hline
\end{tabular}

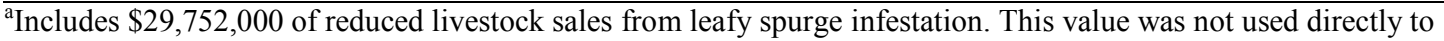
estimate secondary impacts but included here for conceptual completeness.

The secondary and total impacts of leafy spurge infestation (Table 4) were estimated using the North Dakota Input-Output Model (3). The total impact of the present level of leafy spurge infestation includes a reduction in personal income, i.e., the household sector, of $\$ 25$ to $\$ 26$ million or about $\$ 44.20$ per lost AUM (Figure 3). Substantial impacts are also shown for the retail trade sector $(\$ 19.3$ million) and the agriculture (crops plus livestock) sector ( $\$ 13.2$ million). The total reduced business activity for all sectors was $\$ 74.7$ million. (If the initial reduction in livestock sales, about $\$ 30$ million, is added to this figure, the total impact estimate is about $\$ 105$ million.) 
Foregone rancher incomes of about $\$ 3,600$ per 100 -cow ranch and aggregate land value depreciation of $\$ 137$ million, coupled with $\$ 75$ million of reduced business activity, suggest the potential returns from leafy spurge control could be substantial. High levels of foregone business activity, which also represent foregone tax revenues, further suggest public resources could be used effectively to decrease North Dakota's leafy spurge problem.

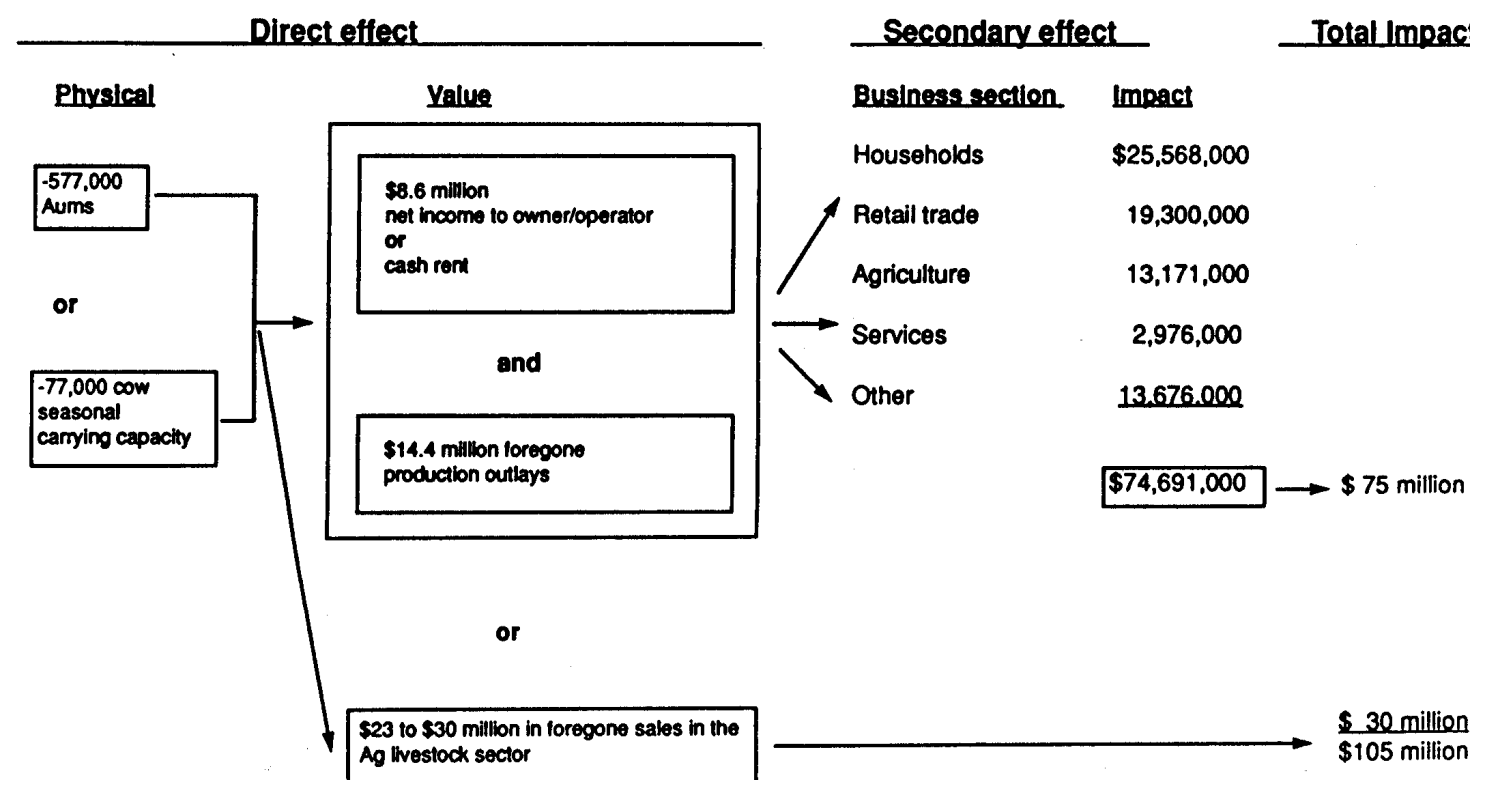

Figure 3. Economic impacts of leafy spurge infestation in North Dakota, 1989.

\section{Acknowledgment}

This study was part of an Animal and Plant Health Inspection Service (APHIS) research program through the Cooperative State Research Service (CSRS) of the U.S. Department of Agriculture.

\section{Literature cited}

1. Carlson, R. B. and L. J. Littlefield. 1983. The potential for biological control of leafy spurge. ND. Farm Res. 40:14-15.

2. Chow, Paul N. P. 1984. Control of leafy spurge in pastures using dicamba and 2,4-D. J. Range Manage. 37:159-62.

3. Coon, R. C., F. L. Leistritz, T. A. Hertsgaard, and A. G. Leholm. 1985. The North Dakota input-output model: A tool for analyzing economic linkages. Agric. Econ. Rep. No. 187. ND. State Univ., Fargo. 54 pp.

4. Ethridge, D. B., B. E. Dahl, and R. E. Sosebee. 1994. Economic evaluation of chemical mesquite control using 2, 4, 5-T. J. Range Manage. 37:152-55. 
5. Ethridge, D. E., R. D. Pettit, T. J. Neal, and V. E. Jones. 1987. Economic returns from treating sand shinnery oak with tebuthiuron in west Texas. J. Range Manage. 40:346-48.

6. Hein, D. G. 1988. Single and repetitive picloram treatments on leafy spurge (Euphorbia esula L.) and resulting changes in shoot density, canopy cover, forage production and utilization by cattle. Ph.D. Thesis. Univ. Wyo., Dep. Agron., Laramie.

7. Hughes, H., D. Aakre, N. Toman, and S. Boyles. 1989. Preparing and understanding a beef cow-calf enterprise budget. ND. State Univ. Ext. Rep. No. EC-971. N.D. State Univ. Ext. Serv., Fargo. 23 pp.

8. Johnson, J. 1990. “Cash rents changed little in 1989.” N.D. Farm Res. 47:28-31.

9. Leistritz, F. L. 1972. Choosing optimum stocking rates for western North Dakota rangeland. Agric. Econ. Rep. No. 81. N.D. Agric. Exp. Sta., Fargo. 20 pp.

10. Leistritz, F. L. and B. L. Ekstrom. 1986. Interdependencies of Agriculture and Rural Communities: An Annotated Bibliography. Garland Publishing, New York. 200 pp.

11. Lym, R. G. and D. R. Kirby. 1987. Cattle foraging behavior in leafy spurge (Euphorbia esula)-infested rangeland. Weed Technol. 1:314-318.

12. Lym, R. G. and C. G. Messersmith. 1985. Cost effectiveness of leafy spurge control during a 5-year management program. N.D. Farm Res. 42:7-9.

13. Lym, R. G. and C. G. Messersmith. 1986. Economic leafy spurge (Euphorbia esula L) control and forage production in pasture and rangeland. Proc. West Soc. Weed Sci. 38:176.

14. Lym, R. G., C. G. Messersmith, and D. E. Peterson. 1988. Leafy spurge identification and control. N.D. State Univ. Ext. Rep. No. W-765 (Revised). N.D. State Univ. Ext. Serv., Fargo. 4 pp.

15. Messersmith, C. G. and R. G. Lym. 1983. Distribution and economic impacts of leafy spurge In North Dakota. N.D. Farm Res. 40:8-13.

16. Mortensen, T. L., F. L. Leistritz, J. A. Leitch, R. C. Coon, and B. L. Ekstrom. 1990. Socioeconomic impact of the conservation reserve program in North Dakota. Soc. Natural Resources 3:53-61.

17. Reilly, W. and K. R. Kaufman. 1979. The social and economic impact of leafy spurge in Montana. Pages 21-24 in Proc.: Leafy Spurge Symp., E. H. Amend, ed. N.D. State Univ., Fargo.

18. Shaver, J. C. 1977. North Dakota rangeland resources 1977. Page 118 in Society for Range Management/Old West Regional Range Program, Denver.

19. Stroh, R. K., D. A. Bangsund, and J. A. Leitch. 1990. Leafy spurge patch expansion formula. AE90001. N.D. State Univ., Fargo. 17 pp.

20. Thompson, F. 1990. Economic impact of leafy spurge on North Dakota grazing land. Master's Thesis. N.D. State Univ., Fargo. 91 pp.

21. U.S. Bureau of the Census. 1989, 1984, and 1981. From the 1987, 1982, and 1978 Census of Agriculture. Washington, D.C.

22. USDA Soil Conservation Service. 1984. Guide to range sites. N.D. Tech. Guide Notice ND-35. Bismarck. 9 pp. 